ISSN (print): 2644-0490, ISSN (online): 2644-0504

Volume 4 Issue 07 July 2021

Article DOI: 10.47191/jefms/v4-i7-25, Impact Factor: 6.228

Page No. 1119-1139

\title{
The MAGNITSKY Law and the RICO Law - The Solution and the Answer against the Order of the Mafia Made by Judge VESSELA EVSTATIEVA and Through the Prosecutors Yaneva, Dimitrova, Stankova, Petrov in Order to Steal Private Property Worth Billions of USD and Caused Losses for US Companies for 8 Billion USD
}

\author{
Lord Prof. PhD PhD Momtchil Dobrev-Halachev \\ Scientific Research Institute Dobrev \& Halachev.JSC., Sofia.Bulgaria
}

ABSTRACT: Lord prof PhD PhD Momtchil Dobrev-Halachev and Prof. Mariola Garibova-DObreva developed 2006 "Theory of degree of democracy" and "Theory of degree of justice / injustice /" based on their practice in court, prosecutor's office, state. Prof. Momchil Dobrev has been creating Theory of Corruption, "Theory of the Mafia," Theory of Mafia "," Financial Banking Resource Technological Mafia Materialism "since 2003"

KEYWORDS: Magnitsky, RICO law, mafia, corruption, theory, finance.

\section{INTRODUCTION}

Lord Prof. PhD PhD Momtchil Dobrev-Halachev and Prof. Mariola Garibova-DObreva developed 2006 "Theory of degree of democracy" and "Theory of degree of justice / injustice /" based on their practice in court, prosecutor's office, state and especially the practice of Prof. Mariola Garibova-Dobreva as a judge for decades experience as such as a civil and criminal judge and Prof. Momchil Dobrev participated as an observer in various types of elections. .

In the year 2001 Lord Prof. Momtchil DObrev developed the Theory of the mafia and Theory of corruption. All the both theories has been developed by analyzing the mafia and the corruption all over the wprld. In Bulgaria, germany, European Union, and other countires.

In the year 2010 Lord Prof. Momtchil Dobrev developed the 'Theory of Mafiotismus' as a new type of government oriented solely in the private interests of individuals and private institutions.

The fight against the mafia and corruption in Bulgaria and in the European Commission and especially in the court and the prosecutor's office is huge, as the prosecutor's office and the court are used by the mafia to steal property, factories, repression, coercion, extortion of honest citizens. In the article we describe one such case, which is striking and proves the huge tentacles of the mafia in court and prosecutor's office in Bulgaria used for theft and racketeering and coercion.

\subsection{Introduce the Problem}

The problem with the mafia and corruption in the court and prosecutor's office in Bulgaria is huge. Through the court and prosecutor's office, the mafia in Bulgaria represses citizens and companies, steals property, steals factories for tens of millions of euros, the court legalizes theft of property, factories, the prosecutor's office is used for repression and pressure, and coercion and extortion to steal property, factories .

Although the European Commission and the European Union are constantly informed about this mafia in court, prosecutor's office, state that the country is run by the mafia, the European Commission and the Union do not take any measures or action.

They obviously have an interest in that.

We have repeatedly applied evidence of the scale of this mafia. The basis of this mafia and corruption in Bulgaria and the European Union and the European Commission, Lord Prof. Momchil Dobrev, established in 2001. Mafia Theory and Corruption Theory with all its manifestations. Based on these theories, Lord Prof. Momchil Dobrev also defines the formula of the mafia, the 
The MAGNITSKY Law and the RICO Law - The Solution and the Answer against the Order of the Mafia Made by Judge VESSELA EVSTATIEVA and Through the Prosecutors Yaneva, Dimitrova, Stankova, Petrov in Order to Steal Private Property Worth Billions of USD and Caused Losses for US Companies for 8 Billion USD

formula of corruption. Based on these processes, Lord Prof. Momchil Dobrev created the Theory and Practice of Mafism, defining a formula of mafia, how it works, how it is organized, in whose interests it works at its expense.

Corruption and the mafia in a country destroy democracy, freedoms, human rights, the rule of law. As a result lor. Prof. Momchil Dobrev and Lady Prof. Mariola Garibova-Dobreva also created "Theory of the Degree of Democracy" and "Theory of the Degree of Justice / Injustice" as well as "Theory of Socio-Humanism" - a society that excludes the shortcomings of neoliberalism, globalism, wild market economy, and creates the foundations of a NEW HUMAN SOCIETY based on completely different principles, as well as economic and social, managerial and others.As a result of the struggle of Lord Prof. Momchil Dobrev against corruption and the mafia in Bulgaria and the European Union and the European Commission since 2011. Lord Prof. Momchil Dobrev experienced 9 / nine / attempted murders of him and his relatives.

As a result and the only solution for the fight against corruption, Lord Prof. Momchil Dobrev sees only the application of the MAGNITSKY LAW and the RICO LAW in the fight against this corruption and mafia in Bulgaria and in the European Union and the European Commission.

\section{RESEARCH METHODS}

Research methods of analysis, verification, control of all factors in corruption and the mafia that affect a society for its viability, the degree of democracy in that society, laws, their implementation by judges, prosecutors, statesmen, ministers, minister Chairs, state and municipal officials and others.

- Analysis of the laws of a country and the European. commission

- Analysis of all authorities in a country - judicial, legislative, executive and the European Union and the European Commission

- Analysis of the implementation of the laws of a country and the European Commission

- Analysis of governance in a country and a society and the European Commission

- Analysis of public resource management in a country and the European Commission

- Analysis of the existence of corruption and mafia in the judiciary, in the state system and in the European Union.

- Analysis of the work of the prosecutor's office as a guarantor of the existence and development of mafia and the rule of law in a society.

- Analysis of the judiciary - laws, judges, selection of judges, development of judges, violations of judges, disciplinary and other liability of judges, prosecutors, investigators, guarantors of democratization in a society

3. The MAGNITSKYy Act and the RICO Act - the guarantee for the fight against corruption and the mafia at the state level in Bulgaria and the European Commission

Theroi Yana Mafia, The Theory of Corruption, Theory of Mafiaism by Prof. Momchil Dobrev. The formulas of mafia, mafia, corruption, degree of democracy, degree of justice

\subsection{The MAGNISTKY Law and the RICO Law}

\section{MAGNITSKY Law}

The Magnitsky Act fights corruption on a global scale, in defense of human rights. The Magnitsky Act fights against every corruption and mafia in a country, against corrupt practices at every level in a country, against corrupt practices. The Magnitsky Act is an opportunity to fight the oligarchy in one country, to fight the mafia in one country, the mafia at any level in one country. The Magnitsky Act became law on December 14, 2012 during the presidency of President Barack Obama.

Magnitsky's law enforcement by the United States occurs when the United States decides to intervene in corruption schemes in a country, its practices, schemes, restrictions on human rights, in order to restore the rule of law.

At the moment, the fight is between crime and the rule of law. When crime has reached its peak, corruption schemes, mafia practices rule in a society, and thus destroy democracy, justice, the rule of law.

The scope of the Magnitsky Act allows the United States to impose sanctions on politicians, government officials, their assistants, and administrations that violate human rights and engage in widespread corruption. The consequences are sanctions, blocking of assets, bank accounts of the sanctioned persons and their relatives of assets around the world, freezing of assets, bank accounts, blocking of transactions, international transfers in dollars. 
The MAGNITSKY Law and the RICO Law - The Solution and the Answer against the Order of the Mafia Made by Judge VESSELA EVSTATIEVA and Through the Prosecutors Yaneva, Dimitrova, Stankova, Petrov in Order to Steal Private Property Worth Billions of USD and Caused Losses for US Companies for 8 Billion USD

\section{THE RICO LAW}

The Racketeer Influenced and Corrupt Organizations (RICO) Act is a United States federal law that provides for extended criminal penalties and a civil cause of action for acts performed as part of an ongoing criminal organization.

The RICO Act focuses specifically on racketeering and allows the leaders of a syndicate to be tried for the crimes they ordered others to do or assisted them in doing, closing a perceived loophole.

For example, before RICO, a person who instructed someone else to murder could be exempt from prosecution because they did not personally commit the crime.

RICO was enacted by section 901(a) of the Organized Crime Control Act of 1970 (Pub.L. 91-452, 84 Stat. $\underline{\text { 922, }}$

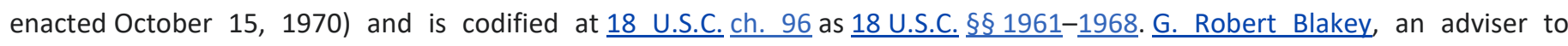
the United States Senate Government Operations Committee, drafted the law under the close supervision of the committee's chairman, Senator John Little McClellan. It was enacted as Title IX of the Organized Crime Control Act of 1970, and signed into law by US President Richard M. Nixon.

While its original use in the 1970s was to prosecute the Mafia as well as others who were actively engaged in organized crime, its later application has been more widespread.

Beginning in 1972, 33 states adopted state RICO laws to be able to prosecute similar conduct.

Under RICO, a person who has committed "at least two acts of racketeering activity" drawn from a list of 35 crimes27 federal crimes and 8 state crimes - within a 10-year period can be charged with racketeering if such acts are related in one of four specified ways to an "enterprise." Those found guilty of racketeering can be fined up to $\$ 25,000$ and sentenced to 20 years in prison per racketeering count. ${ }^{[3]}$ In addition, the racketeer must forfeit all ill-gotten gains and interest in any business gained through a pattern of "racketeering activity."

In many cases, the threat of a RICO indictment can force defendants to plead guilty to lesser charges, in part because the seizure of assets would make it difficult to pay a defense attorney. Despite its harsh provisions, a RICO-related charge is considered easy to prove in court since it focuses on patterns of behavior as opposed to criminal acts.

When the U.S. Attorney decides to indict someone under RICO, they have the option of seeking a pre-trial restraining order or injunction to temporarily seize a defendant's assets and prevent the transfer of potentially forfeitable property, as well as require the defendant to put up a performance bond. This provision was placed in the law because the owners of Mafiarelated shell corporations often absconded with the assets. An injunction or performance bond ensures that there is something to seize in the event of a guilty verdict.

RICO also permits a private individual "damaged in his business or property" by a "racketeer" to file a civil suit. The plaintiff must prove the existence of an "enterprise." The defendant(s) are not the enterprise; in other words, the defendant(s) and the enterprise are not one and the same. .6$]$ There must be one of four specified relationships between the defendant(s) and the enterprise: either the defendant(s) invested the proceeds of the pattern of racketeering activity into the enterprise (18 U.S.C. § 1962(a)); or the defendant(s) acquired or maintained an interest in, or control of, the enterprise through the pattern of racketeering activity (subsection (b)); or the defendant(s) conducted or participated in the affairs of the enterprise "through" the pattern of racketeering activity (subsection (c)); or the defendant(s) conspired to do one of the above (subsection (d)). ${ }^{[7]}$ In essence, the enterprise is either the 'prize, 'instrument,' 'victim,' or 'perpetrator' of the racketeers. ${ }^{[8]}$ A civil RICO action can be filed in state or federal court. ${ }^{[9]}$

Both the criminal and civil components allow the recovery of treble damages (damages in triple the amount of actual/compensatory damages).

3.2./. THE MAFIA IN BULGARIA and the inaction and support of this mafia by the EUROPEAN COMMISSION and the EUROPEAN PARLIAMENT

BULGARIA - THE MAFIA HAS A STATE

THE INACTION AND SUPPORT OF THIS MAFIA BY THE EUROPEAN COMMISSION AND THE EUROPEAN PARLIAMENT.

We will not go into details and therefore we will pay attention to what is the reason for the current state of our country. 


\section{The MAGNITSKY Law and the RICO Law - The Solution and the Answer against the Order of the Mafia Made by Judge VESSELA EVSTATIEVA and Through the Prosecutors Yaneva, Dimitrova, Stankova, Petrov in Order to Steal Private Property Worth Billions of USD and Caused Losses for US Companies for 8 Billion USD}

In our homeland Bulgaria corruption has become the norm. The mafia has become the norm.

Mafia corruption in the court and prosecutor's office in Bulgaria has become the norm.

The court is used for legalized theft of property and factories for tens of millions of euros, the court and prosecutors are used for repression, racketeering, coercion of extortion of companies and citizens to donate and transfer property, companies, factories in favor of the mafia.

The mafia is at a HIGH STATE LEVEL. The Prosecutor's Office with Chief Prosecutors SOTIR TSATSAROV, PROF. BORIS VELCHEV, IVAN GESHEV is used for repression and racketeering and forcing honest citizens and companies to transfer businesses, properties for HUNDREDS OF MILLIONS EURO to people and companies of the mafia.

At the same time, the PROSECUTOR'S OFFICE ACTS and COVERS CRIMES committed by prime ministers, ministers, statesmen, civil servants.

It has become the norm for the prosecutor's office to raise fabricated accusations against dissidents and against fighters against the mafia and corruption.

It is the norm for the main prosecutors such Filchev, Assoc. Prof. Boris Velchev, Tsatsarov and Geshev not to file charges for the theft of property by the oligarchs Emil Kyulev, Donev - properties that belong to the heirs of insurance companies.

It is the norm for the prosecutors of TSATSAROV and GESHEV and for them personally not to bring charges for the theft of land over 2.9 million cubic meters of land from private land, with which the NORTH TANGENT of the city of Sofia was built.

NORM is from 2008. not to be ACCUSED against PEA Dichev, PEA Yakimov, PEA. Cholakov and dozens of other PEAs violated the law. At the same time, the PROSECUTOR'S OFFICE ACTS and COVERS CRIMES committed by prime ministers, ministers, statesmen, civil servants.

The fact that the Prime Minister has appointed the Chief Prosecutor has become the NORM. It is clear why!

The fact that the prosecutor's office does not bring charges against ministers and prime ministers and statesmen has become NORM.

NORMA is the double standard in the prosecution.

NORMA is for prosecutors not to bring charges of theft of land from private lands, with which the North Tangent was built, the theft of slot machines by former judge Yordanka Mollova and her brother Hristo Mollov, the violations of PEA Dichev, the theft for zero pennies of properties for over 500 million euros from EMIL KYULEV and his heirs and from DONEV, thefts of factories, the lawlessness of judges Valkov, Raina Martinova, ALbena Boteva, Desislava Yordanova, Nelly Kutzkova, Eric Vassilev and hundreds of other judges from SRS, SCC SAS, VKSy BOS, KOS, VROS and other courts.

It is the norm for prosecutors in the specialized prosecutor's office to cover up clearly proven crimes committed by judges, legalizing theft of property for hundreds of millions, legalizing theft of property, legalizing theft of equipment for tens of millions, legalizing theft of entire factories, and legalizing openly proven crimes. judges, mayors of the capital and others?!?!?!

NORMA is for prosecutors to delay pre-trial proceedings for years against people supported by the mafia, with the ultimate goal of passing the statute of limitations.

NORMA is for prosecutors to violate the laws of our country with the ultimate goal of fulfilling the order - TIGHTENING ZADAR over a person close to the mafia, an official, a minister, a prime minister, and others.

NORMA is for prosecutors to RAISE ACCUSATIONS against appointed people, critics of the mafia and people of the mafia, who are in violation of the law with the ultimate goal of racketeering, coercion, DESTRUCTION OF HUMAN LIVES, FATE, deterioration of health.

NORM is that prosecutors do not respect the laws when it comes to people close to the mafia,.

It is the norm for prosecutors, in case of indisputable evidence, graphological expertise for fraud on a particularly large scale, to delay investigations in order to pass the statute of limitations against the perpetrators, who boast that they pay prosecutors so as not to bring charges against them.

It is the norm for mafia judges to confirm these terminations by prosecutors despite indisputable evidence. / example M. Lalov /

It is the norm for judges to place orders for the mafia and to issue decisions that legalize the theft of private property in favor of the Sofia Municipality - the GERB representatives.

It is the norm for judges to place orders for the mafia and to legalize thefts of factories, equipment worth tens of millions of euros, theft of property for the benefit of third parties.

NORMA is for judges to terminate cases against banks, insurance companies, state institutions, ministries, the National Revenue Agency, the Ministry of Interior in execution of an order of the executive branch and of mafia companies. 
The MAGNITSKY Law and the RICO Law - The Solution and the Answer against the Order of the Mafia Made by Judge VESSELA EVSTATIEVA and Through the Prosecutors Yaneva, Dimitrova, Stankova, Petrov in Order to Steal Private Property Worth Billions of USD and Caused Losses for US Companies for 8 Billion USD

\begin{abstract}
NORM is to disappear lawsuits filed against Banks for stolen money - hundreds of thousands
INJUSTICE is the NORM.

THE LEGISLATION by judges and prosecutors is NORM.

THE IMPUNITY OF PROSECUTORS AND JUDGES IS NORM.

THE LAWLESSNESS of prosecutors and judges IS THE NORM.

NON-COMPLIANCE OF THE LAW by judges and prosecutors is a NORM.

VIOLATION OF THE LAW by prosecutors and judges NORM.

THE NORM is THE THEFT OF BUSINESS by people from the mafia through prosecutors and judges.

THE NORM is THE THEFT OF PROPERTY by people from the mafia through prosecutors and judges.

THE NORM IS THAT THERE IS NO JUSTICE, THERE IS NO JUSTICE.
\end{abstract}

THE NORM IS THE INACTION OF THE EUROPEAN COMMISSION AND THE EUROPEAN PARLIAMENT despite the application of evidence of the mafia in a country, the mafia in court, the mafia in the prosecution, the mafia in the government of Bulgaria.

Bulgaria is used only for money laundering, 30 to 50 percent of all investments in equipment, machinery, investments are returned to the company of EUROPE and Western countries.

3.3./. CORRUPTION Formula, MAFIA Formula, MAFIOTISMUS Formula, DEMOCRACY FORMULA, JUSTICE / INJUSTICE DEGREE,

CORRUPTION FORMULA / 2001 - Theory of Corruption - Prof. Momchil Dobrev

Corruption $=$ Monopoly rights $/$ rights + laws $/$ rules $/$ practices $/$ procedures + possibility to make an alternative decision obligation - responsibility - morality / ethics.

MAFIA FORMULA - 2001 - Mafia Theory - Prof. Momchil Dobrev

MAFIA = Power + Influence + Relationships + Interests + ORDER / And + Mafia structure / internal or external structure / + Monopoly rights / rights + laws / rules / practices / procedures + possibility to make an alternative decision - obligation responsibility - morality / ethics .

\title{
FORMULA OF MAFIOTISM - 2001 - Theory of Mafiaism - Prof. Momchil Dobrev
}

MAFIOTISMUS = PERSONAL Power / on the top of the state institutions / state and etc./ + Influence + Connections / to personal, private companies + Interests / personal, private, corporative / + ORDER / ORDERS + Personal Management of all state neveaus + Personal Control of all state niveausMafia structure / inside of or outside / + Monopolity Riegths + laws / rules / practices / procedures + possibility of taking an alternative decision - obligation - responsibilities - morality / ethics + Personal management and personnel control another resource.

\section{FORMULA Of DEGREE OF DEMOCRACY / 2006}

DEMOCRACY = POWER - Influence - Relationships - Interests - ORDER / AND - Mafia / mafia structure / internal or external / Monopoly rights + laws / rules / practices / procedures // freedoms // - possibility to make an alternative decision - Obligation Responsibility - morality / ethics - observance / application / enforcement of the law by judges / prosecutors / statesmen Control / Sanction - corruption / corrupt practices - information - manipulation - structure of society - economy - inequality + obligations - Justice / injustice - Trust / Degree of trust

\section{FORMULA of Degree of Justice / Injustice - 2006 - Prof. Momchil Dobrev and Prof. Mariola Garibova-Dobreva /:}

JUSTICE / INJUSTICE = POWER + Influence + Relationships + Interests + MONEY / AND + Mafia structure / internal or external / + Monopoly rights / rights + laws / rules / practices / procedures + possibility to make an alternative decision - Obligation Responsibility - morality ethics - observance / application / implementation of the law by judges / prosecutors / statesmen Control / Sanctions - Corruption - Mafiaization - TRUST / DEGREE OF TRUST.

\section{JUDICIAL SYSTEM - WHAT DEPENDS ON INJUSTICE / JUSTICE IN THE JUDICIAL SYSTEM:}

Legality - pass laws, law enforcement, Duality of law enforcement, confrontation and contradiction PPIETITE law with the Basic Law of control, JUDGMENTS, equality, overseeing compliance with the law by judges overseeing the 
The MAGNITSKY Law and the RICO Law - The Solution and the Answer against the Order of the Mafia Made by Judge VESSELA EVSTATIEVA and Through the Prosecutors Yaneva, Dimitrova, Stankova, Petrov in Order to Steal Private Property Worth Billions of USD and Caused Losses for US Companies for 8 Billion USD

implementation of the law by prosecutors overseeing the implementation of laws by government, ministers ," CONTROL OF IMPLEMENTATION OF THE LAWS OF MUNICIPAL / local authorities overseeing the implementation of laws by ministers and prime minister by the prosecution, the dependence of the prosecution of the executive DEPENDENCE OF pROSECUTION mafia in its favor, DEPENDENCE OF jUDGES OF mAFIA, the violation of law by judges, impunity of judges, impunity prosecutors impunity for officials, CONTROL OF JUDGMENTS by evidence CONTROL OF JUDGMENTS - impose PRACTICE, THE FAILURE OF THE COURT JUDGMENTS OF JUDGES, NON-IMPLEMENTATION OF DIRECTIVE ORDINANTS BY JUDGES EV ROPEYSKATATA Commission and the European Union, FAILURE OF JUDGMENTS H \ EPRILAGANE of judgments DISTORTION OF JUDGMENTS FAILURE OF LAWS, non-LAW, breaking the law, MAFIOTIZATSIYA of the vessel MAFIOTIZATSIYA the prosecution MAFIOTIZATSIYA the state apparatus, MAFIOTIZATSIYA BA THE LOCAL MUNICIPAL APPARATUS, IMPLEMENTATION OF THE CONSTITUTION.

CORRUPTION - DEGREE OF CORRUPTION WITH JUDGES, CORRUPTION WITH PROSECUTORS, CORRUPTION WITH STATES / MUNICIPALITIES / MINISTERS / PRIME MINISTERS, MAFIA MAFIA AND MAFIA MAFIA MAFIA

\section{HUMAN RIGHTS - RESPECT FOR HUMAN RIGHTS, APPLICATION OF HUMAN RIGHTS LAWS,}

4. SPEC|IFIC cases Powered LAW Magnitsky Act and RICO - fulfilling orders from the Mafia judge Vesella EVSTATIEVA, prosecutors Nina Yaneva, Mariana Stankova, Daniela Dimitrova, a prosecutor Petar Petrov extreme to steal private property and causing losses to $\$ 8$ billion

\section{1./. THE BEGINNING}

On 04.04.2008 21.05.2008 by virtue of decrees for assignment D. acquire two properties located in the northern tangent of the city of Sofia - the capital of Bulgaria, respectively with areas of 2050 decares and 2170 decares.

As early as September 2008, pressure began on the father by phone from 11 pm to 3 pm, when DD was invited to donate the property of the then Prime Minister BB and threats. After these threats, DD suffered a stroke, heart attack and broke his leg in the hospital in the city of Burgas. Since September 2008, after an operation in a hospital in Sofia, DD has been in bed in Sofia.

After failing to threaten and racketeer the D. family, former State Security colonels posing as representatives of Prime Minister Boyko Borissov began wanting to buy the property at a price 9,000 (nine thousand) times below market price.

After the rejection of this proposal, actions in various institutions follow.

Following letters from the President of the Chamber of Private Enforcement Agents Private Enforcement Agent Georgi Saykov Dichev, to the National Revenue Agency, to the Prosecutor's Office, to the prosecutors Nikolay Kokinov, to Prosecutor Balev, to the Prosecutor Mariana Stankova, to the Sofia City Prosecutor's Office Mariana Stankova from the Sofia City Prosecutor's Office for appointing tax audits against the whole family and its companies.

After colonels from State Security 2010 and 2011 with an office on Vitosha Blvd. - in the city of Sofia, they offered a former boarding house to the D. family and introduced themselves on behalf of BOYKO BORISOV and offered to buy these lands owned by the D family at a price of 9000 / nine thousands / times below market value?!?!,

And after the members of the D. family refused to sell these lands to the NRA and the prosecutor's office was activated, tax audits began, orders of prosecutor Mariana Stankova for tax audits, foreclosures on all properties of the D. family followed, as well as the process lands 2050 decares and 2170 decares.

The National Revenue Agency is asking the son of the MD family for unpaid taxes for BGN 2,000,000 / two million / BGN 6,000,000 / six million / BGN, BGN 8,000,000 / eight million,

Taxes in the amount of BGN 2,000,000 are demanded from father D and BGN 2,000,000 / two million / from the mother.

THE AUDITS OF THE DATIONAL REVENUE AGENCY IN BULGARIA ENDED WITH AUDIT ACTS FROM WHICH IT IS SHOWN THAT THE PERSONS OF THE FAMILY D. DO NOT OWE ANY CENT OF THE STATE.

Following a complaint from a person representing the support of the GERB party and the MRF party Krassimir Mollov, a prosecutor's file was opened. There are also letters from the President of the Chamber of Private Enforcement Agents Georgi Saykov Dichev to the Prosecutor's Office, the National Revenue Agency, and the Sofia City Prosecutor's Office.

In 2011 the apartment of the D family was set on fire, in 2012 at the beginning of the year a bus was waiting for MD next to his office to push and smash it, but it only passed through his leg. After seven more assassination attempts on MD.

Following is an attempt to steal private property through a Concession by the Council of Ministers with Prime Ministers SERGEY STANISHEV 2009 and Prime Minister BOYKO BORISOV 2010. By Decision of the COUNCIL OF MINISTERS № 43 of 
The MAGNITSKY Law and the RICO Law - The Solution and the Answer against the Order of the Mafia Made by Judge VESSELA EVSTATIEVA and Through the Prosecutors Yaneva, Dimitrova, Stankova, Petrov in Order to Steal Private Property Worth Billions of USD and Caused Losses for US Companies for 8 Billion USD

23.01.2009. with Prime Minister Sergey Stanishev and subsequently with Decision № 69 of 15.02.2010 with Prime Minister Boyko Borisov decides to enter into an ILLEGAL CONCESSION with the company "CELSIAN" on private property for 35 years, as the Council of Ministers has determined and given LAND - additional to a concession area of 2,928.5 in the amount of an additional area of 9,084 decares PRIVATE PROPERTY.

THE PURPOSE IS THE THEFT OF THE PRIVATE LANDS, which back in 2008 the then mayor of Sofia Boyko Borisov declared as his own lands on which he would build a super settlement.

2010 and 2011 the requests for PUP in UAGK of Sofia Municipality for preparation of a detailed development plan DO NOT ACCIDENTALLY DISAPPEAR and so far they do not exist. There are projects to build a power plant for 375 megawatts based on the technologies created in 1991 by MD, stadiums, complexes and others for 5 billion dollars.

4.2. THE MAFIA'S ORDER PROVEN BY THE ACTIONS OF THE PROSECUTORS MARIANA STANKOVA, DANIELA DIMITROVA, NINA YANEVA from the Sofia CITY PROSECUTOR'S OFFICE - JUDGE VESSELA EVSTATIEVA from Plovdiv Court

\subsubsection{INITIATION OF THE ORDER}

This order was initiated by letters from the Chamber of Private Enforcement Agents, PEA Georgi Saykov Dichev as its chairman, other 4 - PEAs qualified as financiers and prepared a Financial Report - fraud of Private Enforcement Agent Ivan Todorov Cholakov, Private Enforcement Agent Iliev I, of Private Enforcement Agent ANgelov.

Prosecutor Mariana Stankova - known from the previous case, instituted pre-trial proceedings against PEA MG who executes an order of the MAFIA in detention of MG, WHICH IS GROSSLY VIOLATED OF THE LAW AND JUDGE GUNCHEV apologizes to MG on behalf of the court, for this MADLESS INJUSTICE AND LAW VIOLATION.

On the other hand, Mariana STANKOVA, who due to this executed order was later raised as a prosecutor in the Supreme Cassation Prosecutor's Office, FORMED PRE-TRIAL PROCEEDINGS FOR THE fact that MG WAS REGISTERING DECISIONS FOR ASSIGNED MG =

The indictment also contains the accusation that PEA M.G. has sold "foreign" properties without taking into account the foreclosure by PEA MG from 30.08.2007 and the properties were sold at a public sale, and the debtor KREMIKOVTSI AD sold the FORBIDDEN PROPERTIES by PEA MG on 30.08.2007 September and November 2007 of third parties - WHICH IS A CRIME UNDER THE CRIMINAL CODE by the management of "KREMIKOVTSI" EAD, the mafia and the prosecutor STANKOVA, INA YANEVA, and DANIELA Dimitrova do not bring charges against "KREMIK".

Ie INSTEAD OF ACCUSING THE MANAGERS OF KREMIKOVTSI AD of SELLING FORBIDDEN PROPERTIES by PEAs to third parties, the exact opposite is being done.

After that, 2014 was attracted and - M.D. for entering and exiting documents in the office of the PEA M.G. by virtue of a contract.

THE ORDER IS PROVEN: Filing a charge, which is accompanied by THREATS OF RACKETS, EXTORTION FROM PEOPLE CLOSE TO THE GOVERNMENT AND THE MAFIA, who threaten and DEMAND MONEY.

It is no coincidence that after the refusal of all this on our part, the PERFORMANCE OF THE ORDER FOLLOWS:

After the judges of the Sofia City Court give their objections to the case in the Sofia City Court, the execution of the order by the judges of the Supreme Court of Cassation follows, namely:

4.2.2. THE FIRST EVIDENCE FOR FULFILLMENT OF THE ORDER OF THE MAFIA AGAINST MG AND MD - THE ORDER OF THE JUDGES FROM THE SUPREME COURT OF CASSATION - RUZHENA KERANOVA, NIKOLAI DARMONSKI AND VALYA RUSHA.

JUDGES of the Supreme Court of Cassation RUZHENA KERANOVA, NIKOLAI DARMONSKI and VALYA RUSHANOVA on April 28, 2017. send the case to look into the nearest SOFIA CITY COURT - Plovdiv Regional Court - although the District Court of Sofia, Pernik District Court District Court Blagoevgrad District court Kyustendil, even DISTRICT COURT PAZARDZHIK are closer to Sofia than DISTRICT COURT PLOVDIV, because there the influence of the then Chief Prosecutor SOTIR TSATSAROV is understandable. The distance to the Plovdiv District Court is $138 \mathrm{~km}$, and to the district courts - Sofia District Court - 0 meters, Pernik - $15 \mathrm{~km}$, Pazardzhik - 100 km, Blugoevgrad 90 km, Kyustendil 70 km. 
The MAGNITSKY Law and the RICO Law - The Solution and the Answer against the Order of the Mafia Made by Judge VESSELA EVSTATIEVA and Through the Prosecutors Yaneva, Dimitrova, Stankova, Petrov in Order to Steal Private Property Worth Billions of USD and Caused Losses for US Companies for 8 Billion USD

4.2.3 THE STATEMENT BY KRASIMIR MOLLOV on July 9, 2020, enjoying the protection of the GERB parties of Boyko Borissov and the MRF of Ahmed Dogan, THAT THE ORDER BY JUDGE JUDGE IS ALREADY BEING IMPLEMENTED BY JUDGE Plovdiv

THE EXECUTION OF THE ORDER AGAINST US WAS PROVED, because on July 9, 2020 the person Krassimir Mollov in the courtroom of the Sofia District Court - Criminal Chamber stated that he would bring for the court hearing in the criminal case in Plovdiv on July 23, 2002 agitation by journalists, WHAT HAPPENED - the journalist VALYA AHCHIEVA,

- THAT HE PAYED THE JUDGE TO SENTENCE MD and MG,

- that the JUDGE WILL ACCEPT ALL FALSE EXAMINATIONS,

- THAT IF THE JUDGE APPOINTS OTHER EXAMINATIONS, THEY WILL BE FRAUD AGAIN,

- THAT THE JUDGE WILL REFUSE THE APPOINTMENT OF HONEST EXAMINATIONS,

- THAT THE JUDGE WILL NOT APPOINT THE REQUESTED EXAMINATIONS AND EVIDENCE,

- THAT THE JUDGE WILL REQUEST INTERROGATIONS OF WITNESSES WITH FALSE STATEMENTS,

- THAT THE JUDGE WILL APPOINT EXPERTS TO PREPARE FALSE EXAMINATIONS,

- That the judge will not comply with the law, will break it, will not respect the law,

- that although the sales were made by the OLD CPC and no tax assessment of the property is required and the initial price of the property is not required to be above the tax assessment, that the judge will require tax assessments that will be FALSE and in violation of the law,

THE PERFORMED ORDER is also confirmed by the legal adviser of Kremikovtzi CHOBANOV in the show of the journalist VALYA AHCHIEVA, broadcast on various media on September 15, 2020 and WATCHED BY MILLIONS OF VIEWERS ON THE INTERNET AND DIFFERENT WATCH, it will last - I hope it will last.

BECAUSE the whole case is an ORDER, which is also proved by the ruling № 64 dated April 28, 2017 of the judges RUZHENA KERANOVA, NIKOLAI DARMONSKI and VALYA RUSHANOVA from the Supreme Court of Cassation with which in violation of the law THEY SEND THE CASE TO POLYVIDVISKY DISTRICT COURT, provided that by law the nearest courts are EVEN the Sofia District Court, the Pernik District Court, the Kyustendil District Court, the Blagoevgrad District Court, the Vratsa District Court, and even the Pazardzhik District. Plovdiv where the people we have been extorted have INFLUENCE AND. and That THIS ORDER IS CONTROLLED BY THE CRIMINAL STATIST BB and his comrade in this SC, who owns the Plovdiv District Court and does whatever he wants in it.

It is no coincidence that Judge Milev drove away because we were told that there was pressure on him to convict us, although he said in the courtroom that there was NO LEGAL FRAMEWORK and subject matter in the case to look at him.

It is no coincidence that the criminal case is on the complaint of Krassimir ASenov Mollov, who since September 2008. and so far he is FORCING MD to TRANSFER $30 \%$ of his land WITHOUT MONEY.

As early as 2008, the father of MD received phone calls in the middle of the night from 1 to 3 in Bulgargas WITH THREATS THAT IF WE DON'T GIVE THE LAND PAID TO B, there will be problems. MD's father suffered a heart attack, stroke and a broken hip in the Burgas hospital from this racket. It is no coincidence that a colonel representing a statesman came to me to demand that we donate the property to this statesman. AND IMMEDIATELY AFTER surname D REFUSES FOLLOWS PRESSURE FROM NRA, Prosecutor's Office and other services.

Not accidentally on 10.05.2010. The NRA imposes seizures of BGN 2,000,000 on all of us - on my mother, my father on Marioala, then additionally on me for 6,000,000 levs, 8,000,000 levs and finally the AUDIT - MOMCHIL DOBREV DOES NOT OWE ANY HUNDRED NAP. It is no coincidence that 2011 is the first ATTEMPT TO KILL OURS - IGNITING OUR APARTMENT.

2012 how BUS passed through me waiting for me for 45 minutes in front of our office.

And then followed SIX MORE ATTEMPTS TO KILL ME AND MY WIFE.

4.2.4. EXECUTION OF . THE ORDER OF THE MAFIA proved by the ACTIONS of Judge VESSELA EVSTATIEVA of the Plovdiv District Court - lawlessness, violation of the laws.

Judge VESELA EVSATIEVA, who twice returned the indictment to the Sofia City Prosecutor's Office in the person of Prosecutor NINA YANEVA, THIRD TIME REFUSES TO RETURN THE INDICTMENT, ALTHOUGH IT IS 100 PARTICLY IDENTICAL TO THE FIRST ONE OF THE FIRST.

This is the beginning of the execution of the order by Judge Vessela EVSTATIEVA. 
The MAGNITSKY Law and the RICO Law - The Solution and the Answer against the Order of the Mafia Made by Judge VESSELA EVSTATIEVA and Through the Prosecutors Yaneva, Dimitrova, Stankova, Petrov in Order to Steal Private Property Worth Billions of USD and Caused Losses for US Companies for 8 Billion USD

three times

The criminal case is TAKEN BY THE WORDS OF THE PEOPLE OF THE MAFIA and Kremikovtzi by Judge VESELA EVSTATIEVA of the Plovdiv District Court, who HAS TAKEN THE CASE - we quote the words of the persons, and the same judge WAS NOT ELECTED BY CASE.

JUDGE EVSTATIEVA, who, in the words of the people of the MAFIA, HAS "ACCEPTED TO SEE THE CASE", FULFILLS THE ORDER OF THE MAFIA to convict innocent innocence in case of indisputable evidence.

\section{EVIDENCE FOR THE ORDER OF THE MAFIA FROM JUDGE VESELA EVSTATIEVA from Plovdiv District Court}

Here we quote some of the things that bother us in the case.

1 /. Judge EVSTATIEVA knowingly erroneously treats indisputable evidence - Judge Evstatieva of the POS when there is an injunction on 30.08.2007. of property to a debtor from the PEA and despite this foreclosure Kremikvotsi sold in September 2007 and November 2007. PROHIBITED properties of third parties. THE JUDGE OF THE MAFIA'S ORDER VESELA EVSTATIEVA DID NOT MENTION THIS PROHIBITION AT ALL FROM 30.08.2007.

2 /. Judge Evstatieva's testimony confirming the correct actions of the PEA confirms the testimony of a witness that these were violations - despite the court decision of the SCC, which proves the RIGHTS of the PEA and the fees due to her.

3 /. Judge EVSTATIEVA knowingly erred in treating written evidence - an effective court decision.

4 /. Judge EVSTATIEVA deliberately uncontested evidence that they have committed falsification of documents were obvious and PROVEN WHEN THEY WERE IN PROSECUTION - the Sofia City Prosecutor's Office by one of the supervising prosecutors Stankova Damitrova or Yaneva or anyone else not to appoint expertise and continues to use these counterfeit documents.

5 /. In the case of Judge EVSTATIEVA, enclosed written evidence over 69 pages that exonerate the defendants disappeared, and despite the missing documents in the subsequent application of the documents, Judge Evstatieva did not accept them deliberately and did not appoint an investigation into who stole the documents.

6 /. Despite the entry into force, it was decided by the Sofia City Court, which proves the lawful actions of the Private Enforcement Agents M.G. Judge Evstatieva treated the decision retroactively in the testimony of a witness.

The amendment in 2017 objectively led to a violation of the right to a fair trial. When returning the case to the relevant prosecutor for elimination of remediable procedural violations with mandatory instructions and return by the Prosecutor's Office without following instructions, the court practically falls into a situation not to oblige the prosecutor's office, but the prosecutor's office to oblige the court to hear the case. On the practical side, the abolition of the provision, which before the amendment in 2017 allowed the court to terminate the investigation to consider the case even in the apparent absence of an act committed by the Penal Code with a crime in order to rule with a final act to acquit the defendant. This continues over time for months and years and puts citizens in a humiliating position to have the quality of defendants, restricts their privacy, is often an obstacle to career development, which the prosecutor's office skillfully uses the rights and competencies given to it to maintain an unfounded accusation against persons, even in the absence of a crime, which violates the right to a fair trial, which is guaranteed by both the CRB and international acts, Human rights

7 /. Judge EVSTATIEVA does not respect the law and does not obey its spirit.

8 /. Judge EVSTATIEVA deliberately changes the content and completes the law

9 /. Judge EVSTATIEVA knowingly misapplied the law.

10 /. Judge EVSTATIEVA deliberately did not cite the law

11 /. Judge EVSATTIEVA deliberately misinterpreted the law

12 /. Judge EVSTATIEVA deliberately mistakenly mixes laws - example old CPC with new CPC

13 /. Judge EVSTATIEVA deliberately wrongly replaces laws - example old CPC with new CPC

14 /. Judge EVSTATIEVA deliberately erred in treating indisputable evidence - Judge Evstatieva of the POS when there was an injunction on 30.08.2007. of property to a debtor from the Private Enforcement Agents and despite this foreclosure Kremikovtzi sold in September 2007 and November 2007. PREVIOUSLY FORBIDDEN PROPERTIES OF THIRD PARTIES - WHICH IS A CRIME UNDER THE CRIMINAL CODE.

Instead of bringing charges against the leadership of KREMIKOVTSI who have sold property confiscated from private individuals, the prosecutor's office in the person of prosecutor MARIYANA STANKOVA, DANIELA DIMITROVA, NINA YANEVA accused Progura of Sofia. 
The MAGNITSKY Law and the RICO Law - The Solution and the Answer against the Order of the Mafia Made by Judge VESSELA EVSTATIEVA and Through the Prosecutors Yaneva, Dimitrova, Stankova, Petrov in Order to Steal Private Property Worth Billions of USD and Caused Losses for US Companies for 8 Billion USD

15 /. When on the basis of a decision of the Sofia City Court confirming the correct actions of the PEA, Judge Evstatieva confirmed the testimony of a witness that these were violations - despite the court decision of the Sofia City Court.

16 /. Judge VESELA EVSTATIEVA knowingly did not allow evidence of the defense that is relevant to the accusation and assisted one of the parties.

Example: Judges Stoitsev and Vanya Goranova of the SRS do not allow information from Raiffeisenbank - whether there was a withdrawal of money and cork on 24 May 2001 and 24 May 2003, according to the pimps. AND IT IS NOTORY KNOWN THAT ON THESE DATES THE BANK BRANCHES DO NOT WORK - HOLIDAY E. Momchil Dobrev was CONVICTED by both judges, after which he was acquitted at the second and third instance.

Judges Stoitsev and Vanya Goranova deliberately did not allow the requested reference.

17 /. Judge EVSTATIEVA knowingly does not accept, does not respect indisputable written evidence proving innocence

18 /. JUDGE VESELA EVSTATIVA DOES NOT READ BANK PAYMENT DOCUMENTS PROVING THAT THE PROPERTIES HAVE BEEN PAID.

19 /. JUDGE VESELA EVSTATIEVA DID NOT READ UNCONDITIONAL EVIDENCE FROM THE NATIONAL REVENUE AGENCY AND THE NATIONAL INSURANCE INSTITUTE OF BULGARIA THAT THE PERSON MD 2010 IS NOT AN EMPLOYEE OF PEA MG $€$

20 \%. JUDGE VESELA EVSTATIEVA DID NOT READ THE EXPERTISE WHO QUOTES BANK TRANSFERS AND PAID MONEY ON THE PUBLIC SOLD, DOES NOT READ DOCUMENTS FOR AMOUNTS AMOUNTED ON THE CASH REGISTER

\section{It's the same as.}

Example: Judge TSENOV who in the distant 2004. received the order to put a completely HEALTHY PERSON in the insane asylum, for which he was promised a lift in the Sofia City Court by Svetlio and Joro, as well as a lift in the Supreme Court of Cassation by Rumen.

Despite the preparation of triple, five - four expert examinations psychological - psychiatric examinations, Judge TSENOV does not respect them, does not accept them, and appoints another such expertise - ORDERS FROM A JUDGE.

21 /. Judge EVSTATIEVA knowingly fails to enforce an effective court decision

22 /. Judge EVSTATIEVA deliberately rendered a decision retroactive to an already entered court decision with the same subject and the same case.

23 /. the judge deliberately does not apply the law because the defendant is his fellow judge on the example of

Example Judge Kacherilska from the SRS terminates

24 /. Judge EVSTATIEVA deliberately disregards decrees of other institutions such as the National Revenue Agency - ENTRY INTO FORCE, REVISION ACTS - ENTRY INTO FORCE FOR AMOUNTS PAID ON PUBLIC SOLD.

25 /. JUDGE EVSTATIEVA did not even comment on the indisputable oral evidence gathered

26 /. Judge EVSTATIEVA did not comply with a court decision which had already entered into force and was binding on him in connection with the subject matter of the present case.

27 /. JUDGE EVSTATIEVA DOES NOT EVEN MENTION ANY ATTACHED WRITTEN EVIDENCE, DOES NOT EVEN DISCUSS THEM IN HIS DECISION, THERE ARE NO REASONS, NO EVIDENCE HAS BEEN DISCUSSED -

28 /. JUDGE EVSTATIEVA does not admit evidence, does not quote, DOES NOT EVEN MENTION THE TESTIMONY of the witnesses which are objective and impartial - THEY DO NOT EVEN MENTION

29 /. JUDGE EVSTATIEV deliberately DOES NOT ALLOW EVIDENCE CONCERNING THE SUBJECT OF THE CASE

30 /. JUDGE EVSTATIVA CONSCIOUSLY DOES NOT ATTACH THE RELEVANT ACT TO THE RELEVANT ARTICLE OF THE CRIMINAL CODE AND INVENTS HIMSELF AND GOES TO THE MOST STRICT COURT.

31 /. JUDGE EVSTATIEVA, in case of indisputable evidence of forgery of documents, clearly and provenly in the Prosecutor's Office of the Sofia City Prosecutor's Office by the PROSECUTORS, did NOT APPOINT AN EXPERTISE and continued to use these forged documents.

32 /. JUDGE VESELA EVSTATIEVA, although one EVIDENCE two enforcement cases are COMPROMISED - SEIZED IN VIOLATION OF THE LAW AND BY LAW THEY CANNOT BE USED, EVEN MORE THAN THE BOTH ENFORCEMENT CASES ARE COMPLETED this VESELA EVSTATIEVA DOES NOT EXCLUDE THESE COMPROMISED FALSE EVIDENCE FROM THE PROSECUTOR'S OFFICE, BUT USES THEM - AGAIN IN VIOLATION OF THE LAW.

33 /. In the case presided over by JUDGE VESELA EVSTATIEVA, enclosed written evidence over 69 pages that exonerate the defendants disappeared, and despite the missing documents in the subsequent application of the documents, Judge Evstatieva did not accept them and did not appoint an investigation into who stole the documents. 
The MAGNITSKY Law and the RICO Law - The Solution and the Answer against the Order of the Mafia Made by Judge VESSELA EVSTATIEVA and Through the Prosecutors Yaneva, Dimitrova, Stankova, Petrov in Order to Steal Private Property Worth Billions of USD and Caused Losses for US Companies for 8 Billion USD

34 /. Despite the entry into force, it was decided by the Sofia City Court, which proves the lawful actions of the Private Enforcement Agents M.G. Judge Evstatieva treated the decision retroactively in the testimony of a witness.

35 /. Judge VESELA EVSTATIEVA knowingly erred in treating indisputable evidence when there was an injunction on 30.08.2007. of property to a debtor from the PEA and despite this foreclosure Kremikvotsi sold in September 2007 and November 2007. foreclosed properties of third parties.

36 / .Judge EVSTATIEVA and knowingly with indisputable evidence that forgery of documents was committed openly and proven in the Prosecutor's Office Sofia City Prosecutor's Office, does not appoint an expert and continues to use these forged documents.

EVIDENCE FOR EXECUTION OF ORDERS OF THE MAFIA FROM THE PROSECUTORS - Mariana Stankova, Daniela Dimitrova, NINA YANEVA, PROFESSOR PETAR PETROV - CRIMINAL LAWLESSNESS, TWO DOUBLE AND TWO-TWO.

\section{Case studies}

1/. Prosecutors Mariana Stakova, Nina Yaneva, Petar Petrov, Daniela Dimitrova do not respect the law, do not follow the law, do not comply with it

2 /. Prosecutors appoint experts who serve the mafia and the prosecutor's office and are ready to prepare any false expertise

3 /. Prosecutors appoint an expert to prepare a graphological examination, which is both false and claims the opposite of the truth of the testimony of a WITNESS.

4 /. Prosecutors Mariana Stankova influences the process and the evidence by appointing experts close to the mafia to prepare appraisal, accounting, graphological, psychiatric and other expertise, as well as officials in dependence, who give obviously incorrect appraisals, such as property appraisal. at prices, for example, 500 times above normal market prices.

5 /. Prosecutor MARIANA STANKOVA appoints an expert, often from the system of the Ministry of Interior, who is ex officio dependent on the investigating police officer and the governing bodies in the system, which works under an employment contract, which graphological expertise often gives incorrect answers to the question whose signature is examined. This is deliberately substituting the evidence and in case of impossibility of the pre-trial proceedings to challenge such expertise may objectify a non-existent accusation. There are cases in which the person whose signature is examined does not dispute the signature and testifies that the document bears his signature, but depending on the order and in order to give the appearance of sufficient evidence of a crime committed by one person, charges are brought, which often fall in the courtroom and lead to acquittals and engagement. the liability of the state for damages under the SMRDA and the ECHR.

6 /. Prosecutors MARIYANA STANKOVA, NINA YANEVA, DANIELA DIMITROVA bring charges for a crime committed by another person by imposing crimes, which is contrary to the law and practice.

Prosecutors MARIANA STANKOVA, NINA YANEVA, PETAR PETROV do not respect international laws.

7 /. Prosecutors Mariana STANKOVA, NINA YANEVA, DANIELA DIMITROVA, BALEV deliberately erred in enforcing the law, accusing the PEA of selling properties that it had seized on 30.08.2007. of public sales in the beginning of 2008, provided that after the foreclosure on 30.08.2007. Kremikovtzi sold them to third parties on 02.112007. and 09.09.2007 despite the foreclosure of the properties - ie. there is a proven crime by Kremikovtzi employees, but for these prosecutors this is not a crime - that of Kremikovtzi.

\section{8/. Prosecutors Mariana Stankova and Nina Yaneva Petar Petrov deliberately did not cite the law}

9 /. Prosecutors Mariana Stankova, Nina Yaneva, Daniela Dimitrova, Petar Petrov deliberately mistakenly treated the law and mixed the old Code of Civil Procedure with the new Code of Civil Procedure, which is very different from the old one.

10 /. Prosecutors Nina Yaneva, Mariana Stankova, Petar Petrov deliberately mistakenly mixed laws - the same as above Prosecutor Yaneva mixed old PC with new CPC -

11 \%. Prosecutors NINA YANEVA, PETAR PETROV, Dimitrova, Stankova deliberately mistakenly treat indisputable evidence, which is not in their favor and in their indictments.

12 /. Prosecutors Stankova, Dimitrova, YANEVA deliberately do not even comment on indisputable written evidence - crimes committed by other persons.

13 /. Prosecutors Nina YANEVA, Stankova, Dimitrova PETAR PETROV knowingly do not execute a court decision that has entered into force

14 /. Prosecutors NINA YANEVA and PETAR PETROV deliberately disregard decrees of other institutions that have entered into force of the National Revenue Agency for proven facts and circumstances. 
The MAGNITSKY Law and the RICO Law - The Solution and the Answer against the Order of the Mafia Made by Judge VESSELA EVSTATIEVA and Through the Prosecutors Yaneva, Dimitrova, Stankova, Petrov in Order to Steal Private Property Worth Billions of USD and Caused Losses for US Companies for 8 Billion USD

15 /. Prosecutors Mariana STANKOVA Daniela Dimitrova, PETAR PETROV, NINA YANEVA do not even comment on indisputable collected written evidence - payments by bank transfer.

16 /. Prosecutors NINA YANEVA, PETAR PETROV do not comply with a court decision that has already entered into force, which is binding on them, in connection with the subject matter of the present case.

17 /. When a prosecutor appoints experts and orders them to prepare accounting expertise and instead of complying with the law and determining prices of non-categorized land - soles - non-categorized land assessed by law and regulation at a price of BGN 40 per decare, determines prices from BGN 18,000 to 28,000 decare - which is 450 TIMES OVER THE LEGAL and designation of non-categorized lands AS LPR for construction of 10-storey buildings. Prosecutors Mariana Stankova, Dimitrova, Yaneva.

\subsubsection{SOME FACTS AND EVIDENCE}

THE LIES OF CHOBANOV - the legal adviser of KREMIKOVTSI, who acquired properties from Kremikovtzi and a multi-property property in the whole country, IN WHAT HE SAID will happen, in violation of any laws Directives, Regulations of the European Union and the European Commission makes a record of us:

1 / - DECISION 1998B dated 18.05.2009. on chgrd. 5116/2007 of the Sofia City Court, judges Genika Mihailova, Nikolay ENchev and Svetoslav Vassilev, which shows that the complaint of "EXPRESSLY WRITTEN" PEA does not collect from the creditor - creditor of the claim with an employment source, in advance fees, and assigns them to the debtor. THE CREDITOR OF THE RECEIVABLE IS THE PEA, not the creditor, but the debtor - the DEBTOR FOR ENFORCEMENT. "

This proves that what Chobanov said is not true.

le performance fees due to PEAs are collected by PEAs from the DEBTOR - "KREMIKOVTSI - AD.

le the liabilities under 233 dated 15.01.2008 in enforcement case 161/07 in the amount of EUR 1,187,165.90 and the other fee on account under $87 / 07$ in the amount of EUR 17,000 are due by the debtor KREMIKOVTSI AD.

2. /. The obligations under enforcement case $87 / 07$ of the debtor Kremikovtzi as a debtor is not only 2253.60 euros, 257.46 euros, but there is a DEBT TO ADV in the amount of 407,650 euros, AS WELL AS DUE FEES TO PEA under the PEA Act in the amount of at 11,055.04 EURO and 4 Euro cents /, on enforcement case 161/07

Certificate from 18.02.2008 for amounts due to the State Receivables Agency from KREMIKOVTSI in the amount of EUR 17,813.95, EUR 323,249, as well as a liability of EUR 2,048,042.96 to the Basin Directorate for Enforcement Case 161/07. le THERE IS NOT ONLY A DEBT OF 2252 EUROS, BUT MILLIONS OF EUROS. Obligations in enforcement cases - fees under the Private Enforcement Agents Act Account under Art. 79 of the Private Enforcement Agents Act number 00195 dated 17.10.2007. on enforcement case 87/07 in the amount of EUR 18,487.40 as well as Account under Art. 79 with number 000233 from 15.01.2008. in enforcement case 161/07 for obligations for fees from the debtor KREMIKOVTSI for the amount of EUR $1,189,165.90$ / one million one hundred and seventy-nine thousand one hundred and sixty-five / EURO.

3 /. The written evidence cited below PROVES THE FALSE STATEMENTS FROM THESE PERSONS AND IS NOT TAKEN INTO ACCOUNT BY JUDGE VESELA EVSTATIEVA \$ BANK TRANSFERS as follows:

1.1./. under enforcement part 20078620400161/07 joined to enforcement case 20078620400087/07 - were paid by M. M.D. and from D.D.D:

- on 28.03.2008 the amount of 2200 EURO deposit, deposit in the amount of 875 EUR, deposit amount of 1750 EURO deposit, the amount of 206.93 EURO deposit was paid by bank transfer to a special account in SiBank.

- on 04.04.2008 the amount of EUR 15,890 surcharge, the amount of EUR 20,580 surcharge, the amount of EUR 1908 surcharge, the amount of EUR 7713 surcharge, by bank transfer EUR 206 surcharge, deposit for the property in the amount of EUR 2,680, deposit deposit by bank transfer - deposit 2200 euros.

On March 28, 2008 deposit 1780 EURO and deposit of 2050 EURO, surcharge of 19070 EURO .and surcharge of 19950 EURO.

The respective amounts for payment were also paid on 21.04.2008, 20.05.2008, 14.05.2008, 16.04.2008. and then there are five bank payments in the amount of EUR 43,000, EUR 45,000, EUR 37,800 and others, as well as cash amounts.

le the above evidence PROVES THE LIES TOLD - LIES on the part of legal counsel CHOBANOV, prosecutor NINA YANEVA, THAT THE PROPERTIES HAVE NOT BEEN PAID AND THAT NOTHING WRITTEN IN THE JUDGMENT OF THE JUDGMENT FROM THE JUDGMENT OF THE COURT OF JUDGMENT.

THE NON-COMPLIANCE OF JUDGE EVSTATIEVA WITH BANK DOCUMENTS FOR PAYMENT AND CASH PAYMENT PROVES A PERFORMED ORDER FOR THE PURPOSE OF THEFT OF PROPERTY. 
The MAGNITSKY Law and the RICO Law - The Solution and the Answer against the Order of the Mafia Made by Judge VESSELA EVSTATIEVA and Through the Prosecutors Yaneva, Dimitrova, Stankova, Petrov in Order to Steal Private Property Worth Billions of USD and Caused Losses for US Companies for 8 Billion USD

4.2.6. THE INCLUSION OF THE JOURNALIST VALYA AHCHIEVA IN THE SCENARIO FOR FULFILLMENT OF THE ORDER OF THE MAFIA and of Judge EVSTATIEVA, which allows the actions of the journalist in the building of the District Court of Plovdiv, NAROSH NARUSH NARUSH.

Despite the fact that she violates the Bulgarian and European legislation, Valya Ahchieva makes a broadcast and even though she has the RIGHT OF ANSWER sent to her, she does not publish it, in violation of any laws, directives, regulations and ethical rules !!!!

With the broadcast on 15.09.2020, the journalist Valya Ahchieva committed numerous violations of the Bulgarian and European legislation on the manner of media coverage, on the good practices and rules for professional ethics of the journalist, as the most striking violations are: Article 32 of the Constitution of the Republic Bulgaria, according to which no one has the right to be photographed and photographed without his consent, of Article 31 para. 3 of the Constitution of the Republic of Bulgaria violation of the presumption of innocence, which is reflected in Article 16 of the Criminal Procedure Code, as well as abuse of information about us that would violate Article 32, paragraph 1 of the Constitution of the Republic of Bulgaria regarding the inviolability of our private life and our right to protection against unlawful interference with it and against encroachment on honor, dignity and reputation

The program grossly violated basic principles proclaimed by domestic and international law, namely:

1. The presumption of innocence was violated. The principle of publicity of the trial ensures public control over the court in order to achieve justice, legality and independence of the proceedings, but in strict compliance with ensuring a fair trial, according to the norm of Article 31 para. 3 of the Constitution of the Republic of Bulgaria innocence and Article 16 of the Code of Criminal Procedure, as well as the Convention on Human Rights - Article 6 and Article 8, Article 46 and Article 47 of the Charter of Fundamental Rights of the European Union, Article 14 of the International Covenant on Civil Procedure and political rights and Article 11 of the Universal Declaration of Human Rights.

Through the so-called "media justice" as the program in question is obviously aimed at unlawful pressure on the court through the expectations of the public in informing it in violation of the cited legal norms of conviction. Obviously through this media presence the journalist aims to influence public opinion, through which, although indirectly, pressure will be exerted on the court when considering the case on the merits, which at this stage has an unfinished judicial investigation with a final judicial act. Such behavior is not only reprehensible but also inadmissible in a state governed by the rule of law.

In this regard, the Council of the European Union, the European Commission of Human Rights and the Supreme Court of Cassation accept for consideration and uphold claims for non-pecuniary damages for damage to goodwill by adversarial disclosure of metrics, which leads to payment of huge compensation .

2. The directive of the European Commission and the Personal Data Protection Act regarding the disclosure of a name, marital status to the public has been violated. When publishing judicial acts, the courts observe the requirements of the provision of Article 86, item 13 of the Judiciary Act and this publication refers only to those that have entered into force, which is done by using initials, but not with the names of This obligation is set out in Article 64 of the Judiciary Act, and in this case it is a matter of disclosing information from a judicial investigation in an unfinished trial. The availability of personal data, including the names of individuals, expressed in the Opinion of the CPDP on the application of the LPPD in the media messages provided by the courts, after publication may become publicly available on the Internet and create preconditions for building unwanted profiles of people as such, as a result of automatic processing, most often by country of Internet search service providers.

3. In violation of the Rules of Ethics of the journalist Ahchieva has prepared and broadcast a program without taking the opinion of all parties, which is inadmissible and DOES NOT EVEN PUBLISH THE RIGHT OF ANSWER.

The person Krassimir Mollov, who was given on July 9, 2020, stated in MG:

"IF YOU DON'T PAY ME AND DICHEV one million each, I will forever deprive you of your rights as a Private Enforcement Agent on my complaint !!".

"I HOPE IT WILL BE SUPPORTED BY THE JUDGE WHO HAS DECIDED TO CONSIDER the case. And as far as I understand, the prosecutor, for one reason or another, will NOT BE THE SAME ..."

What happened on September 21, 2020?

PROSECUTOR NINA YANEVA DOES NOT APPEAR IN THE COURT HALL. Ie WHAT THE LEGAL ADVICE CHOBANOV SAID Came true.

JEFMS, Volume 4 Issue 07 July 2021 www.ijefm.co.in Page 1131 
The MAGNITSKY Law and the RICO Law - The Solution and the Answer against the Order of the Mafia Made by Judge VESSELA EVSTATIEVA and Through the Prosecutors Yaneva, Dimitrova, Stankova, Petrov in Order to Steal Private Property Worth Billions of USD and Caused Losses for US Companies for 8 Billion USD

\section{Question WHERE IS THE INFORMATIVE INFORMATION CHOBANOV INFORMED ABOUT THIS INFORMATION, WHICH TURNED OUT TRUE.}

le The legal counsel CHOBANOV KNOWS WHAT WILL HAPPEN IN THE COURT, WHAT WILL HAPPEN IN THE FUTURE, AND WHAT WILL HAPPEN IN THE CASE.

IE THE MAFIA WORKS.

This is another proof of an FULFILLED ORDER of the MAFIA against us.

\section{$2 /$. VIOLATIONS OF JUDGE VESSELA EVSTATIVA in passing sentence:}

The texts described in the protocol "on the grounds of Art. 37 item 6 of the Penal Code deprives the defendant MG of the right to exercise the profession of state and private bailiff, as well as their assistants and to hold a state position requiring legal education" is entered "on the grounds of art. 37 item 6 of the Penal Code deprives MD. From the right to hold any activity with a Private Bailiff and to hold a public office requiring higher legal education "

These texts of the sentence sent to us have not been read and did not exist as an integral part of the sentence.

Once read in public, the sentence cannot be changed by the same panel. The addition of these texts took place after reading the sentence, which was criminally corrected, which is inadmissible and constitutes a crime committed by the members of the court - for Judge Evstatieva a crime in office, and for members of the court a document crime. Moreover, the deprivation of the right to practice a profession is under Article 37, item 7, and not under Article 37, item 6 of the Penal Code.

The competent authorities were notified of the case for immediate inspection and after establishing the above to take appropriate measures for each of the notified bodies - for the Prosecutor's Office to initiate pre-trial proceedings against members of the judiciary, the Minister of Justice and members of the SJC. to request and initiate disciplinary proceedings against Judge EVSTATIEVA with a request to impose the most severe punishment disciplinary dismissal and removal from office, for jurors deleting them as such from the list of jurors.

Already in September in a court hearing on 21.09.2020. The recusal of the court panel was requested for reasons filed by me and the other defendant civil case against Plovdiv Regional Court for damages caused to us as a result of the violation committed by the court in the present case of basic procedural and guaranteed by the Constitution of the Republic of Bulgaria and international law. human rights - Article 6 violations, namely our right to a fair trial by an impartial court. This request was made each time in open court and it is not an end in itself, on the contrary it was made in time ten months ago so that it can be quickly The main motives are the admission of the journalist Valya Ahchieva to a protest in a court hearing on 23.07 .2020 and the broadcast prepared by her. In this show, MG and MD are presented as criminals and the presumption of innocence is violated.

Moreover, there are lawsuits filed against the Plovdiv District Court and against JUDGE VESELA EVSTATIEVA personally and the jurors from 01.06.2021. filed in the Plovdiv District Court, and attached with the request for recusal and also such cases in the Sofia City Court. Despite these cases, Judge Vessela EStatieva and the jurors refused to leave.

ONLY THIS IS A GROUND FOR REVOCATION OF THE JUDGMENT AND RETURN OF THE CASE TO THE COURT OF FIRST INSTANCE.

Violated right to defense. At a court hearing on 09.06.2021 the request of the defendant $\mathrm{G}$. was not granted, who presented a sick note issued by LKK-medical consultative commission with a diagnosis of bronchiectasis. This is a disease associated with aggravated underlying disease COPD-chronic pulmonary obstructive disease to postpone the hearing.In severity it is equivalent to severe pneumonia, as it is characterized by inflammation of the lungs, from which inflammation can lead to death due to respiratory failure. At the court hearing, she expressed an opinion that she did not object to the case being initiated solely for the interrogation of the expert graphologist, so as not to waste it and to postpone the court hearing. This not only did not happen, but the court debate. This deprivation and my fundamental constitutional right are grounds for reversing the sentence and remanding the case for consideration by another panel, joining her request for reversal of the sentence and remanding the case at first instance, as this violation cannot be removed-

The case is not within the jurisdiction of the Plovdiv District Court, regardless of the decision of the Supreme Court of Cassation, as the court investigation has been terminated several times and the fact that a significant period of time has elapsed at the time of the appointment of the PSC, which is not an obstacle. In this sense, there are many decisions that determine the conclusion that after the termination and return of the case to a pretrial hearing, the representative of the Prosecutor's Office should file the indictment in this court, which he This is another ground for reversal of the sentence and return of the case for a new hearing by another court equal in degree, and in this case by the Sofia City Court. 
The MAGNITSKY Law and the RICO Law - The Solution and the Answer against the Order of the Mafia Made by Judge VESSELA EVSTATIEVA and Through the Prosecutors Yaneva, Dimitrova, Stankova, Petrov in Order to Steal Private Property Worth Billions of USD and Caused Losses for US Companies for 8 Billion USD

Another violation - the fundamental right to defense. The practice of the Supreme Court of Cassation is when the competent court cannot form a panel to send the case to the nearest district court equal in degree. In this case the POS is not the closest, but obviously the MOST CORRECT COURT IN view of the stated Vladimirova that they have a strategy with Kremikovtzi and the fact that the former Chief Prosecutor SOTIR TSATSAROV worked in the Plovdiv District Court as its chairman.

This is a separate ground for reversing the sentence.

The accusation under item 1 of the OA. According to the provision of the Civil Procedure Code, the Jl draws up a report for each of its actions. The inventory is an action, which is objectified in a drawn up report and in cases when it reflects incorrect data of the Penal Code, as the inventory protocol is an official document drawn up by an official, what quality does sub.G.

REALLY, AS THE ACCUSATION AND THE JUDGMENT ARE FREE WORKS.

THE MOST IMPORTANT CIRCUMSTANCE THE PROHIBITION made on 30.08.2007 IT IS REGISTERED BY A REGISTRATION JUDGE, WHO HAS CHECKED THESE CIRCUMSTANCES AND HAS BEEN CONVINCED THAT THESE ARE THE PROPERTIES OF KREMIKOVTSI, AND NOT TO A THIRD PARTY, IF THEY DO NOT CONCERN WRITTEN INTO INNOCENT.

\section{Evidence of injustice and incorrectness of the sentence}

Enforcement case $87 / 07$ is not separate from enforcement case 161/07. Enforcement case 161/07 was joined to enforcement case 87/07 in accordance with the Civil Procedure Code with all actions performed under this enforcement case $87 / 07$, - injunctions, inventories and others.

In enforcement case $87 / 07$ is dated 30.08.2007. foreclosure of all property, of which the debtor has been notified. On 30.08.2007 there is also an inventory from 12.00 to 19.00, proving that we were with PEA M.G. at 12:00 on 30.08.2007. and we have stated this ois, in the presence of a police officer from the 5th District Police Department - even two police officers. The foreclosure of all properties of the debtor on 30.08.2007. is a case in the Registry Agency, and is contained in the case.

The debtor was notified as of the inventory on 30.08.2007. and for the foreclosure of property.

In this enforcement case, even with the Invitation for voluntary execution, the debtor is invited to pay the amount due of EUR 47,000 to the State Receivables Agency, the state which is under the Civil Procedure Code is an associated creditor. The debtor does not pay any of his obligations both to the creditor, the natural person and to ADV. The debtor does not pay until the date of 2009. and its obligations for the fee and costs of the enforcement case to the PEA-MG. As can be seen from the evidence, the valuations of these properties in the inventory dated 30.08.2007. are three to seven times higher than the tax assessments of the respective properties. Even the announced initial price for the property apartment in Mladsot-4 is 15,000 euros higher than the price at which Kremikovtzi ILLEGALLY DESPITE THE FORBIDDENING OF THE PROPERTY by PEA MG HAS SOLD TO THE THIRD PARTY ........

The same applies to the assessment of the apartment in Suhata Reka....

Since enforcement case 161/07 uses all actions - inventories and foreclosures carried out in enforcement case 87/07, since $161 / 07$ is joined to $87 / 07$. The allegation that PEA M.G. has sold properties that have already been sold. This is not true.

These properties were confiscated on 30.08.2007. .

These properties were sold illegally in September and November 2007. from the debtor Kremikovtzi to third parties in violation of the law GPK and Penal Code, separately the obligations to the natural persons - creditors the debtor Remikovtsi has obligations to NRA-ADV. By law, the debtor's debt to the NRA or ADV is automatically joined as an associated creditor in the respective enforcement case. According to the first use. Case 87/07 the debt of the debtor Kremikovtzi to the National Revenue Agency is BGN 950,000. As can be seen from the certificate of ADv. The debtor Kremikovtzi was served with Invitations for voluntary execution in both enforcement cases - under the old Civil Procedure Code in which the obligations to ADV-NRA were entered, respectively. During the voluntary execution the debtor Kremikovtsi has not paid a penny of these obligations.

In addition, according to the Decision of the Sofia City Court attached and accepted in the case, the fees due by the debtor for the general obligation, search fees, foreclosures, fee item 26 are due to the PEA, even if the respective amount to the creditor is paid under the obligation. In this case In this case four months after the invitation for voluntary execution the debtor pays the debt to one creditor in enforcement case 87/07, but does not pay his debt to ADV - NRA. The obligation to ADV - NRA is paid directly to him and not through the special account of PEA-MG. in enforcement case 87 / 0-7 the debtor after four months directly pays his debt of 475,500 EURO to ADVV - NRA. Since this amount is considered collected by law - the debtor owes item 26 on this amount of BGN 950,000 which according to the Tarfiac is EUR 18,000 and is invoiced to account 79 of the Private Enforcement Agents Act which is attached and accepted in the case. 
The MAGNITSKY Law and the RICO Law - The Solution and the Answer against the Order of the Mafia Made by Judge VESSELA EVSTATIEVA and Through the Prosecutors Yaneva, Dimitrova, Stankova, Petrov in Order to Steal Private Property Worth Billions of USD and Caused Losses for US Companies for 8 Billion USD

According to the decision of the Sofia City Court for this case, the court ruled that the due fees of BGN 35,000 are due by the debtor under item 26 of the Tariff to the PEA. As long as there is an obligation to the PEA, the enforcement case cannot be terminated accordingly. Moreover, enforcement case $161 / 07$ has been joined to enforcement case $87 / 07$ in this way, in order to terminate enforcement case $87 / 07$, all amounts must be paid - to all creditors, to NAP, AD in the due fees under enforcement case 161/07.

The debtor was sued and received an invoice for the due state fees in enforcement cases and account 79 of the Private Enforcement Agents Act, respectively - for amounts.

Therefore, the law is impeccable, the fact that the prosecutor's office claims something outside and in violation of the law does not surprise us.

Despite the fact that the debtor Kremikovtzi has paid his debt to the National Revenue Agency, he owes the amounts to the PEA. As long as these amounts are due to the PEA, the enforcement case cannot be terminated. In this regard, the statements of the prosecutor's office that the PEA continues the enforcement actions and does not correspond to the truth are untenable.

Under enforcement case 161/07, the liabilities of KREMIKOVTSI to the National Revenue Agency amount to EUR 2,450,000, as evidenced by a certificate of ADV. They have been reassigned to the obligations under the enforcement case and the State Tax Inspectorate has been assigned to the claimant in the enforcement case. Even with an inventory made on 08.01.2008. respectively, the debtor owes not only the amounts under enforcement case 87/07 under and under enforcement case $161 / 07$. In enforcement case 161/07 there are joined creditors with receivables from the debtor Kremikovtzi and for other amounts in the amount of EUR 11 million. The debtor was notified in a timely manner of invitations for voluntary execution, which is also proved by the return receipts received from the debtor. The debtor was also notified of all obligations under the taxes due to the PEA. In the enforcement case we have applied fees under item 26 all fees to PEA MG. in the amount of EUR 1230000.

With regard to public sales, pursuant to the Law, apart from the fact that the PEA filled in deeds for the respective property, which is subject to public sale, they allowed themselves to hand these deeds to the clerks in the respective municipalities, although they did not have one. obligation under law. No PEA does that. The PEA has an obligation to affix only the notice in the respective municipality. PEA MG has handed over these announcements for public sale in the office of the respective municipality, for which signatures have been received. Witnesses testified that they had received these advertisements for public sale and had placed them in a prominent place. All this was done legally.

Judge VESELE EVSATIEVA's assertion that the amounts for the public sales have not been paid is unfounded. It is evident from the evidence attached to the case that one part of the wasp was paid by bank transfer, another part of the cash register. And this is done under the old Civil Procedure Code, since the public sales made by PEA D are under the old Civil Procedure Code, not under the new Civil Procedure Code. PEA or by bank transfer. Under the new Civil Procedure Code, the amounts are paid only by bank transfer.

Since all public sales carried out under item 161/07 are made under the old Civil Procedure Code, there are both possibilities for payment of the amounts - both at the box office and on the special account of the PEA in a bank.

One of the experts confirmed that cash payments can be made, as the PEA has the role and status of a company. All payments, both by bank transfer and at the box office, are legal - as they are made under the old Civil Procedure Code.

The attached accounting expertise proved that there were payments in the amount of EUR 50,000, EUR 42,500, EUR 43,500, EUR 42,500, which were not reported by Judge VESELA EVSTATIEVA.

The expertise proved that all payments by bank transfer were made by MMD and DDD, which is proved by the graphological examinations that these payments are also import documents and payment documents are written and signed by these two persons MMD and DDD. le does not answer anything from what was written by Judge VESELA EVSTATIEVA that MDe received the amounts of transfers from the PEA to his companies, and then paid them to the bank.

NOTHING proves the allegation that MD was an assistant private contractor, which was taken blindly by the prosecutor's office, a fictitious allegation based on no evidence and FACTS.

Only MD has carried out clerical work, has never and in no way PREPARED DOCUMENTS OR AS A PRIVATE BAILIFF OR ASSISTANT PRIVATE BAILIFF. Amab is only a power of attorney from PEA MG. To submit and receive documents.

The debtor's obligation Kremikovtzi under case 161/07 to the NRA in the amount of EUR 2,450,000 has never been paid.

The accounting and graphological expertise proves in an indisputable way that the documents for depositing the money with import notes at the cash desk of SiBank were signed and prepared by MMD and DDD, and were not signed or prepared by MD. They have never been drafted and submitted, and signed by the MD. 
The MAGNITSKY Law and the RICO Law - The Solution and the Answer against the Order of the Mafia Made by Judge VESSELA EVSTATIEVA and Through the Prosecutors Yaneva, Dimitrova, Stankova, Petrov in Order to Steal Private Property Worth Billions of USD and Caused Losses for US Companies for 8 Billion USD

In the case it is proved in an indisputable way that all the amounts on the public sales have been paid only there is a corresponding overpayment. For one property the decree was issued under Art. of the Civil Procedure Code, which allows the amount to be paid and paid at a later date together with the legal interest for this.

About the cession. The assignment agreement has been concluded with NED OIL COMPANY. This is a legal entity, this assignment agreement was concluded with the person because he needed money for his treatment, and Kremikovtzi had not paid anything. And because the creditor had problems with his health. NED OIL COMPANY is a creditor of Remikovtsi in the bankruptcy case and so far not a single penny has been paid on this obligation of the debtor Kremikovtzi to Ned Oil Company. As can be seen from the Commercial Register, Kremikovtzi has been declared bankrupt since 2009 and the foreclosure, which is the creation of a property in Kremikovtzi, is for security purposes, but no damages have been changed, ie Cossack does not correspond to the truth.

What was written by Judge VESELA EVSTATIEVA does not correspond to the fact that the Private Enforcement Agent MG continued its actions on condition that the amount was paid to the creditor in one case. Exactly the opposite in this enforcement case and so far the debtor has not PAID THE AMOUNTS OF COSTS IN THE CASE WHICH THE DEBTOR OWES TO PEA MG, ie. it cannot be terminated.

On the first case 87/07 the amounts due to the PEA MG under item 26 are within 17,500 EURO, They were not paid until 08.01.2008. even so far, i.e. there are no offenses in violation of the law.

Since 161/07 was executed, $87 / 07$ was joined.

With regard to the appraisals of the properties, it has been indisputably proved that the appraisals that were performed on 30.08.2007. are three to five times higher than the tax assessments. It turned out that the price of the public sale of the property in the Suhata Reka residential area, which was sold in violation of the law after the foreclosure of 30.08.2007. by PEA MG at the public sale conducted by PEA MG was sold at $30 \%$ higher price.

The same applies to the property in zh.k. Mladost-4, i.e. the properties were sold at more than $35 \%$ higher prices than the KREMIKOVTSI themselves, in violation of the law, had sold to third parties.

With regard to the bombastic appraisals of property 00083 and 00230 in the case, we have indisputably proved that since the properties are uncategorized, out of regulation and according to a certificate of the Ministry of Agriculture these properties are uncategorized, not even agricultural land, and the relevant regulations apply. uncategorized lands, property, ie soles and embankments. These properties according to the regulations of the Republic of Bulgaria and relevant laws, the assessment is BGN 40 per decare. The estimates determined by the PEA MG are between 9 and 12 times higher than the respective estimates, it has been proved that two properties had to be determined.

In an indisputable way it is dakazon, it is with the real tax assessments are such, and not those that are applied under the February 2021 tax. for property 00230, that these tax assessments are prepared in violation of the law, moreover, that the certificate of the Ministry of Agriculture for these properties these properties are not only non-categorized, they are also out of regulation. The expert's assessments are determined that the Kyoto loan is in regulation and, respectively, for a property that is built of a 5-7-storey building.

There is no material evidence in the present case, as it has not been destroyed. The very fact that the two enforcement cases were seized in the original, in violation of Art. 22 of the Private Enforcement Agents, proves that there is no written evidence. The only written evidence that is valid is the foreclosure from 30.08.2007. and, respectively, the entries in the Award Decree, the Entries in the Assignment Decrees, are entered by the buyers themselves, and not by the PEA MG.

Regarding the amounts transferred to my two companies, there is a contract concluded from 20.10.2006. for the respective activities, which are performed in the office of PEA MG, respectively $50 \%$ are due to one company $30 \%$, and to the other $20 \%$ of fees, which are collected and due to the PE. Everything was done by law and no violation was committed.

It is not true that MD is an employee of the office of the Private Enforcement Agent MG and an assistant private bailiff. As can be seen from the written evidence only from 2015. MD has an employment contract with PEA MG as a natural person. Before that he did not have any employment contract, only there were order contracts with the companies ET Snemo Mars - MD and DiM D. Consulting House dated 20.10.2006.

There is no crime under Art. 282 of the Penal Code.

As can be seen from the certificate to the Plovdiv District Court ref. Number00067 from date 12.06 .2020 on all public sales payments have been made under LAW - OLD CPC in the total amount of 734383 euros. The evidence was accepted by application 33 and application 28 
The MAGNITSKY Law and the RICO Law - The Solution and the Answer against the Order of the Mafia Made by Judge VESSELA EVSTATIEVA and Through the Prosecutors Yaneva, Dimitrova, Stankova, Petrov in Order to Steal Private Property Worth Billions of USD and Caused Losses for US Companies for 8 Billion USD

As can be seen from the certificate to the Plovdiv District Court, ref. Number 00098 / 30.09.2020 Account № 000233 dated 15.01.2008 under Art. 79 of the Private Enforcement Agents Act under Art. Case 161/07 fees are due item 26, item 20, item 11, item 5, item 12 by the debtor KREMIKOVI to PEA MG. in the amount of EUR 1,186,117.

On account № 000195 dated 17.10.2007. under Art. 79 of the Private Enforcement Agents Act on enforcement case 87/07 the debtor KREMIKOVTSI owes to the Private Enforcement Agents Mariola Garibova fees under item 26, item 20, item 26, item 11, item 5 and item 12 in the total amount of BGN 36,978.48 / thirty-six thousand nine hundred and seventy-eight levs and 48 stotinki /.

PURSUANT TO THE LAW CPC and CPA on one distribution FIRST ARE PAYABLE FEES - costs to the PEA, and then any other amounts are due to creditors, associated creditors, NRA, ADv and others.

For both accounts under Art. 79 of the Private Enforcement Agents Act, the debtor has been NOTIFIED of which he has signed the relevant notices - personally legal counsel Lalev and a return receipt.

These two accounts are part of accounting.

FRAUD is written that the MARKET VALUE of an apartment in MLADOST 4 - is 37800 EURO more soft Kremikovtzi sold to RUMYANA IVANOVARUSINOVA on November 2, 2007. in violation of the law foreclosed property - the same apartment ONLY FOR 20000 / twenty thousand / EURO.

Ie THERE IS FRAUD, which WE PROVED, but Judge VESELA EVSTATIEVA DID NOT ACKNOWLEDGE the fraud.

FRAUD is written that the market value of an apartment in zh.k. Suhata Reka is 28,215 euros, moreover, the debtor KREMIKOVTSI sold on September 4, 2007. DESPITE THE PROHIBITION of 30.08.2007 THE SAME PROPERTY FOR 15375 EURO.

THIS IS A FRAUD.

FRAUD is written is the market value of property 000230 is 15430000 EURO even more that it is proved that the property is non-cassette land, out of regulation and according to the Ordinance one decare market value is ONLY 20 EURO, ie. THE MARKET ESTIMATE OF THIS OMIT IS 41,000 EUROS.

FRAUD is written that the market value of property 00083 is 7366000 EURO, moreover that it has been proven that the property is uncategorized land out of regulation and according to the Ordinance one decare of market value is ONLY 20 / twenty / EURO. i.e. THE MARKET VALUATION OF THIS PROPERTY IS ONLY 43,000 EUROS.

It is proved that estimates for these properties, given by PEA M. Garibova are 8 / eight / - 10 TEN / TIMES BIGGER THAN THE REAL ones.

It has been proved that for a property READY with an area of 16517 DESTROYED - THE AMOUNT OF 34,000 EUROS IS NECESSARY for clearing the property from destruction. le the given market valuation of $104-00$ euros IS FRAUD.

THE OTHER ASSESSMENTS ARE A SCAM.

The Ordinance for categorization of agricultural lands in case of change of their purpose from 1996. proved that according to Art. 1 para 3 - mines, embankments, soles are NON-CATEGORIZABLE land - tenth category and according to Ordinance on the procedure for determining the prices of agricultural land from 2006 SG no.

INDICATIVE FROM THE ACCEPTED AND ATTACHED EVIDENCE Decree of 21.07 .2011 on item case 95/2007 by Judge STANISLAVA KAZAKOVA which ruled the assignment of the neighboring to these two PROPERTIES property number 00100 to the company "Metaltrade INnenerring 2 EOOD" 66 EOOD. m. , i.e. by 30\% thirty percent on a large property from the above quoted ONLY AT A PRICE OF 337,050 EURO.

THIS PROVES AGAIN THE FRAUD IN THE ASSESSMENT given by the expert.

Moreover, the debtor KREMIKOVTSI HAS RECEIVED ALL ISSUED CONTRACTING DECREES, HAS NOT PITYED ANYTHING, has agreed with them.

"IN ADDITION, IT HAS BEEN PROVED THAT for two properties 0083 and 00230 recultivation and rehabilitation is required, which for the respective properties amounts to BGN 62 million and BGN 68 million, according to the law on rehabilitation and reclamation.

ORDINANCE № 26 for reclamation of disturbed terrains of October 22, 1996.

EVEN MORE THAT THE MARKET VALUE WAS APPLIED for reclamation of only 78.3 decares for the AMOUNT of 1238338 EURO. le the money for reclamation for property 00230 WHICH IS NECESSARY is 31383131 euros.

$33,776,700$ euros are needed for the reclamation of property 0083.

THESE AMOUNTS FOR RECURRENCE SHOULD BE DEDUCTED FROM THE MARKET VALUATION OF THE PROPERTY.

Moreover, the MARKET VALUE OF THE PROPERTY 000230 dated 03.06.2011. ONLY 8430 EUROS. 
The MAGNITSKY Law and the RICO Law - The Solution and the Answer against the Order of the Mafia Made by Judge VESSELA EVSTATIEVA and Through the Prosecutors Yaneva, Dimitrova, Stankova, Petrov in Order to Steal Private Property Worth Billions of USD and Caused Losses for US Companies for 8 Billion USD

\section{5/. THE PARALLEL ACTIONS OF THE MAFIA IN THE COURT - SOFIA CITY COURT AND SOFIA DISTRICT COURT supported by the SOFIA COURT OF APPEALS and THE SUPREME COURT OF CASSATION}

\section{FOR EIGHT YEARS, THERE HAS NOT BEEN A SINGLE COURT SESSION IN THE CASES SUBMITTED IN THE SRS AND SCC FOR THE} PROPERTIES IN QUESTION

KREMIKOVTSI AD takes over 2013. commercial cases for all purchased and PAID PROPERTIES.

However, instead of the cases being terminated by the JUDGES OF THE SOFIA CITY COURT, who PROVENLY FULFILLED THE ORDER OF THE MAFIA, the cases are not commercial, and the same cases were filed in violation of the law only 5 / five / years after the issuance of the procedural act and four years after of the plaintiff KREMIKOVTSI in bankruptcy.

In reality, under the commercial law, Kremikovtzi will not have the right to conduct these cases, and if it has filed them, THE CASES ARE OVERDUE - four years AFTER THE APPLICABLE - THE MANDATORY TERM of one year after declaring Kremikovtzi bankrupt, ie. May 2009.

FOR MORE THAN 8 / EIGHT / years the judges VLADIMIR VALKOV, RAYNA MARTINOVA, ALBENA BOTEV, LYUBKA GOLAKOVA, ALEXANDER ANGELOV from the Sofia City Court have not terminated the cases.

Despite the fact that the judges VLADIMIR VALKOV, RAINA MARTINOVA, ALBENA BOTEVA, ALEXANDER ANGELOV have recused themselves in other cases for one of the parties.

Refusal to suspend works and to fulfill the law is confirmed by the judges of the second instance Sofia Appellate Court - judges Koutskova Ivanka Angelova, KRASIMIR MASHEV golden RUBIEVA Daniela DONCHEVA Nelly Koutskova, YANA Valdobrev, Nikolai MITANOV, MADLEN JELEVA, Galina Ivanova, Vasil Hristakieva, ATANAS KEMANOV, ASEN VODENICHAROV IVAN IVANOV.

Moreover judges Koutskova, Ivanka Angelova, KRASIMIR MASHEV golden RUBIEVA Daniela DONCHEVA Nelly Koutskova, YANA Valdobrev, Nikolai MITANOV, Galina Ivanova, Vasil Hristakieva, ATANAS KEMANOV, ASSEN VODENICHAROV have given arresters in cases of family D when they are were judges in lower courts - SOFISKI GRADSKI SA. Instead of withdrawing in these cases, THEY CONFIRM THE REFUSALS TO TERMINATE THE CASES.

THIS IS A VIOLATION OF EUROPEAN LAW and unscrupulous proof of a contract.

ALL PROPERTIES, for which investments in the amount of 5 billion US dollars have been prepared by AMERICAN COMPANIES, the claims have been entered and the real owners can do nothing - NO INVESTMENTS, NO INVESTMENT INVESTMENT.

Moreover, the judges from Sofia Gradsi Court Evgeni GEORGIEV exempts KREMIKOVTSI from paying millions of Euro-due state fees, WHICH IS ANOTHER CRIME COMMITTED BY A JUDGE, which was confirmed by Judge Kf.

THE BUDGET OF THE REPUBLIC OF BULGARIA YAS MILLIONS EURO IS DAMAGED.

And this happened in the Sofia City Court, when the presidents of the judges ALEKSEY TRIFONOV, KALOYAN TOPALOV, POPKOLEVA, if EVGENI GEORGIEV, YANEVA.

Chairs of the Sofia Court of Appeal are DANIELA DONCHEVA, PENGEZOV.

Judge Claudia MITOVA from the Sofia District Court did not even close the case for two properties that KREMIKOVTSI had actually sold, and no owners are real, AND EVEN THOUGH THEY ARE DOING THIS CASE, JUST TO DO DAMAGES - TO DAMAGE

Judge KLAUDIA MITOVA herself, a former prosecutor from the SRS in the case, stated that ALL JUDGES FOLLOW the criminal case in PLOVDIV, and are guided by gova.

THAT IS WHY THERE HAS BEEN NO COURT SESSION FOR MORE THAN 8 / EIGHT / YEARS in the cases filed by KREMIKOVTSI.

Ie THE EXECUTION OF THE ORDER FROM JUDGE VESELA EVSTATIEVA FROM PLOVDIV IS WAITING FOR THE EXECUTION OF THESE CIVIL CASES.

6/. THE INACTION OF THE MAIN CHIEF PROSECUTOR IVAN GESHEV, the Chairperson of the Plovdiv District Court Sheitanova and Deputy The chairwoman MARIA SHISHKOVA - close to SOTIR TSATSAROV

The inaction of the members of the Supreme Judicial Council and Inspector TOCHKOVA

Inactivities of the main manager of PLOVDIV APPELATIVE COURT Magdalena IVANOVA and Michaela BUUKLIEVA. The activities are WAITED from THEM?!?!?!?

Despite dozens of prosecutions with attached evidence of OBVIOUS VIOLATIONS and EXPRESS AND PROVEN CRIMES committed by Prosecutor NINA YANEVA, MARIANA STANKOVA, Judge VESELA EVSTATIEVA or Chief Prosecutor IVAN GESHEV. The President of the Plovdiv District Court SHEYTANOVA and Judge MARIA SHISHKOVA close to the former Chief Prosecutor 
The MAGNITSKY Law and the RICO Law - The Solution and the Answer against the Order of the Mafia Made by Judge VESSELA EVSTATIEVA and Through the Prosecutors Yaneva, Dimitrova, Stankova, Petrov in Order to Steal Private Property Worth Billions of USD and Caused Losses for US Companies for 8 Billion USD

SOTIR TSATSAROV and his former deputy. Chief Prosecutor, DO NOT IMPLEMENT Art. 312 of the Judiciary Act and do not want reprimand for Judge VESELA EVSTATIEVA - her disciplinary dismissal.

Despite the signals, the members of the Supreme Judicial Council from the panel of judges - Georgi Cholakov - Supreme Administrative Court, Atanaska Disheva, Boryana Dimitrova, Krassimir Shekerdzhiev, Olga Karelska, Sevdalin Mavrov, Tsvetinka Pashkunova, Boan Magdalin, do not do and do not implement this law. Veronika Imova, Daniela Marcheva, Dragomir Koyadzhikov, Stefan Grozdev as well as the Chief Inspector at the SJC Mrs. TOCHKOVA.

7/. THE SIGNALS TO THE PROSECUTOR'S OFFICE AND THE CHIEF PROSECUTOR IVAN GESHEV for the violations of Prosecutor NINA YANEVA and Judge VESSELA EVSTATIEVA

Despite the SIGNAL to the Chief Prosecutor IVAN GESHEN for crimes committed by Prosecutor NINA YANEVA - Prosecutor in the SGP, falsification of documents in the criminal case and falsification of volumes 4 and 5 where there are FALSE SIGNATURES AND STAMPS OF WHICH NO of the Chief Procurator IVAN GESHEV.

Chief Prosecutor IVAN GESHEV DOES NOT CHARGE Prosecutor NINA YANEVA.

This is ANOTHER PROOF OF HOW OFFICIAL DOCUMENTS ARE FALSIFIED IN THE PROSECUTOR'S OFFICE AND CRIMES ARE REALLY COMMITTED AND THESE DOCUMENTS ARE APPLIED FOR USE IN CASE.

\section{8/. PROVEN CRIMES COMMITTED BY THE EXPERT Miroslava Nikolova KUNCHEVA - prepared FALSE EXAMINATIONS}

THESE ARE ORDERED EXPERTS - THE EVIDENCE !!!

Provided that a given land has the status of TABAN, - UNCATEGORIZED LAND and according to the Ordinance on valuations of such lands one decare costs only 20 euros, the expert Miroslava KUNCHEVA ESTIMATES LAND, WHICH IS NOT EVEN AGRICULTURAL LAND AS EVERYTHING ON THIS LAND HAS THE RIGHT TO BUILD A TEN-STOREY BUILDING and evaluates one decare instead of 20 euros, THE SAME ESTIMATES IT as a land plot - worth 48,000 euros per decare and HIGHER ..

\section{9/. LOST INVESTMENTS FOR AMERICAN COMPANIES PREPARED INVESTMENTS IN 2014 IN THE AMOUNT OF 5 BILLION USD \\ THE PURPOSE is to steal property from the MAFIA.}

10 /. During this time 2015-2016, 2.9 MILLION CUBIC METERS OF LAND EQUIPMENT worth EUR 75 million were stolen from the SINGLE PROPERTY in the amount of EUR 75 million in 2020 and 2021 through the Agency for Cadastre Cartography and Geodesy in the form of an obvious factual error. THE MAFIA STERA AND THEFT 25948 acres worth a total of $\$ 2$ billion.

11 /. THE PROTECTION OF PROSECUTOR PETAR PETROV from the Plovdiv District Prosecutor's Office with consumer and mortgage loans for over EUR 150,000 proves COMPLETE INCOMPETENCE and COMPLETED ORDER.

\section{CONCLUSION}

Described case PROVES HOW IT WORKS CONTRACT OF MAFIA FOR THIS TO BE rob PROPERTIES cost billions of US dollars from individuals how desyvuva Uы COURT PROSECUTOR'S OFFICE AND HOW to be performed mafia prosecutors and courts in Bulgaria.

\section{LITERATURE REVIEW}

1) Dobrev, M. (2015) Theory of generating crises, Bulukrain-MM, Sofia, BG

2) Dobrev, M. (2016). Is there a mafia in the European Commission and Union?!? 1, Bulukrain-MM Sofia.BG

3) Dobrev, M. (2014). Theory of the corruption and Theory of the mafia, Bulukrain-MM, Sofia., BG

4) Dobrev, M. (2013). Theory if degree of trust, Bulukrain-MM, Sofia, BG.

5) Dobrev, M. (2010). Theory and praxuse of the Mafiotismus. Bulukrain-MM. Sofia

6) Dobrev, M. (2019) "The mafiotism in the EU, ECommission, E Parliament!?!?! And its protection with Gemany, France, Englans - the mafia in court, prosecutors, government in Bulgaria over ten years !!! The dept of EC and EU of houndret billions USD !!! "Bulukrain-MM. Sofia

7) Dobrev. M. (2018) "Theory and practice of Mafiotismus. Finance-banking resource technological mafia-driven Materialism"- Bulukrain-MM, Sofia 
The MAGNITSKY Law and the RICO Law - The Solution and the Answer against the Order of the Mafia Made by Judge VESSELA EVSTATIEVA and Through the Prosecutors Yaneva, Dimitrova, Stankova, Petrov in Order to Steal Private Property Worth Billions of USD and Caused Losses for US Companies for 8 Billion USD

8) Dobrev, M., Garibova-Dobreva, Mariola (2020) The new old world order.- Bulukrain-MM, Sofia

9) Dobrev, M, Garibova M, /2020/ The Mafia, Mafia and Financial Bank Resource Technological Mafia Materialism - THE NEW OLD WORLD ORDER Bulukrain-MM

10) Dobrev M. Goribova-Dobreva. /2020/ THE PLAN FOR COVID 19 THE PANDEMIC - THE THIRD WORLD WAR - the attempt to impose a NEW WORLD ORDER by the representatives of Promf Momchil Dobrev financial banking resource technological mafia Materialism for control of the whole planet, nations, people, Euro, children, USA and companies. Bulukrain-MM

11) Dobrev. M. Garibova-Dobreva M. /2020/RESTART OF CIVILIZATION - without mafia and financial banking resource technology in mafia Materialism - THE ONLY SOLUTION! Our suggestion. Bulukrain-MM

12) Dobrev, M. Garibova-Dobreva, M. /2020 חRESIDENT DONALD TRUMP and TRUCK'S DOCTRINE against mafiaism, financial banking resource technological mafia materialism, Wars, the new Old World Order1 Our proposal for RESTART OF CIVIL. Bulukrain-MM

13) Dobrev. M., Garibova-Dobreva.M. /2020/ THE GREAT RESET with the COVID-19 the real "the Third World War" - to impose a NEW WORLD ORDER on the new Holocaust, genocide, dictatorship of DIGITAL MAFIOTISMUS. Bulukrain-MM.

14) Dobrev. M, Garibova-Dobreva.M. / 2020 / The COVID-19 pandemy - the real "the Third World War" - to impose a NEW WORLD ORDER on the new Holocaust, genocide, dictatorship of DIGITAL MAFIOTISMUS. Bulukrain-MM

15) Dobrev,M. Garibova.M. /2018/ THE GENIUS OF PROF. MOMTCHIL DOBREV- HALACHEV and his theories, Theory of degree of trust, Theopry of degree of truth, Theory of mafia, Theory of corruption., Theory of vortex fields. Theory and practice of free energy. Cosmological theory of information. Theory of information-energy-medicine, - genetics, psychology, - psychoiatry, - archeology., Theory and practice of mafiotismus, Theory of unversum, Finance-bankinh resource technological mafia-driven Materialismus Bulukrain-MM. 